\title{
Névtorzítás és alakpárhuzam a krimiirodalomban
}

1. Bevezetés. „egészen különös megjelenésű emberke volt. Nem sokkal volt magasabb százhatvan centinél, de nagyon méltóságteljesen viselkedett. Tökéletes tojásfeje volt, s egy kissé mindig félrebillentette. Bajusza tömött, nagyon katonás. Öltözékének makulátlansága szinte hihetetlen; egy porszem bizonyára nagyobb fájdalmat okozott volna neki, mint egy revolvergolyó" (Christie 1990a: 25).

Okkal feltételezhető, hogy e rövid jellemzés alapján még azok is rájönnek, kinek a neve szerepel az általam kipontozott részen, akik nem különösebben jártasak a krimiirodalomban. Mindenekelőtt azért, mert egy világhírü szerző világhírü szereplöjéről van szó, s az idézet tartalmazza a karakter beazonosításához szükséges legfontosabb diagnosztikai tulajdonságokat (ECO 2009: 88). Alacsony termet, tojásfej, méretes bajusz, makulátlan öltözet - ennyi elegendő ahhoz, hogy az olvasó az Hercule Poirot nevet társítsa a figurához. A hivatkozott regény megjelenése idején (1920), mely kötet az írónő első munkája volt, ez még persze korántsem volt így. Az azóta eltelt időszakban azonban további regények, novellák, illetve színházi, filmes és képregényes adaptációk sora gondoskodott arról, hogy a felsorolt tulajdonságjegyek szinte automatikusan hívják elő a befogadók emlékezetében a belga magándetektív nevét és alakját.

Hercule Poirot nem hétköznapi figura, miként a neve sem az. A fizikai külső és néhány jellemző szokás ismeretében ugyanakkor nehéz nem észrevenni a névadás mögött meghúzódó iróniát. Ez mindenekelött a görög eredetű, jelentős mitológiai és múvészeti hagyományt maga mögött tudó keresztnév vonatkozásában ragadható meg: Poirot megjelenésében és tetteiben nincs semmi herkulesi vonás. De vajon más szempontból is alaptalan a két karakter összevetése?

A kérdés a szerzőnek a Hercules munkái (The Labours of Hercules, 1947) címü novelláskötete első, felvezető történetében (Előszó) is felmerül, mely a detektívnek és barátjának, doktor Burtonnak a beszélgetését tartalmazza. Az utóbbi kérdez rá a névadás motivációjára: „Ez aligha keresztény név [...] Kifejezetten pogány. De miért? Ezt szeretném tudni. A papa hóbortja? A mama szeszélye? Családi okok?" (Christie 1990b: 7; kiemelés az idézett forrásban). Poirot kitér a válaszadás alól. Barátja finom csipkelődés kíséretében célozgat a fizikai külsejükben megnyilvánuló kontrasztra, s egyúttal a klasszikusok tanulmányozására buzdítja őt. Ennek köszönhetően ismerkedik meg később Poirot behatóan Herkules tetteivel. Finoman szólva nincs különösebben elragadtatva sem tőle, sem a többi mitológiai hőstől. „Mi más volt, mint egy alacsony intelligenciájú és bünöző hajlamú izomkolosszus!" (Christie 1990: 13). Az antik héroszok a bünözőket juttatják eszébe, nemcsak a tetteik, hanem a névhasználat okán is: „Ezek az istenek és istennők... úgy tünik, több különböző álnevük volt, csakúgy, mint a modern bünözőknek. Az igazat megvallva határozottan bünöző típusúnak látszanak. Ivás, kicsapongás, buja dorbézolás, vérfertőzés, nemi erőszak, fosztogatás, emberölés, körmönfontság... állandóan lekötnének egy vizsgálóbírót. Sehol rendes, példás családi élet. Semmi rend, semmi módszer. Még a büncselekményeikben sincs 
rend, vagy módszeresség!" (Christie 1990: 13; kiemelés az idézett forrásban). Mikor nem sokkal ezután a tükörbe pillant, jóleső érzéssel nyugtázza magában, hogy különb görög előképétől, nemcsak fizikailag (,teljesen más, mint az a dagadó izmú, buzogánnyal hadonászó visszatetsző meztelen alak"), hanem jellemét és szellemi kvalitásait tekintve is: úgy gondol magára, mint egy modern „találékony, elmés, mulatságos és önhitt” Herkulesre (Christie 1990: 14). A lesújtó vélemény ellenére azonban nem határolódik el teljes mértékben a hérosztól. Felismeri ugyanis kettejük között a párhuzamot, ami hasonló sorsbéli rendeltetésükben nyilvánul meg: „mindketten eszközök, hogy a világot a kellemetlen emberektől és bizonyos gonosztól megszabadítsák... Mindkettőről elmondható, hogy jótevője a társadalomnak, amelyben élt" (Christie 1990: 14).

A szereplőnek a narrátor szólamába illesztett felismerése egy olyan, a konkrét eseten túlmutató, általánosabb érvényü önazonosító és önértelmező mủvelethez visz közel bennünket, amely e tanulmány egyik elméleti kiindulópontját képezi. Poirot a névegyezésnek köszönhetően von párhuzamot maga és Herkules, tehát egy mitológiai-irodalmi alak között. Láthattuk, hogy ambivalens viszonyulásról van szó, melyben a részleges eltávolítás és az azonosulás, az idegenség és az ismerősség tapasztalata vegyül egymásba. Herkules a detektív számára egy olyan viszonyítási pontot képez, amihez képest, amire való tekintettel sikerül újrafogalmaznia önmaga személyiségét és a társadalomban betöltött szerepét. Nagyon hasonlóan járunk el olvasóként mi is, ha a Poirot nevet viselö vagy a belga detektívre valamilyen szempontból emlékeztető szereplővel találkozunk más szerzők műveiben: esztétikai konkretizációnkat az egyező és különböző tulajdonságjegyek mérlegelése kíséri. Csak éppen megváltozik a viszonyítás alapját képező minta, Herkules helyett Hercule Poirot ruházódik fel az eredeti figura státuszával, a görög-római mitológia helyett pedig Agatha Christie Poirot-regényei és -novellái jelentik majd a detektív külsejére, jellemére és tetteire nézve irányadó szövegbázist.

A továbbiakban három ilyen mü, két novella és egy regény rövid elemzésére teszek kísérletet, különös tekintettel a névadás poétikai motivációira és a fiktív tulajdonnevek értelmezésorientáló szerepére. Annyi már most előre bocsátható, hogy kiemelt szerep jut majd benne a névmódosítás, közelebbről az elbeszélói vagy a szereplői szólam részeként megjelenő szándékolt névtorzítás müveleteinek, illetve azok karakterformáló hatásának. A vizsgált esetekben a teljes vagy részleges névegyezés az intertextuális olvasás felé nyit utat, más szóval: a szereplö neve a szövegközi allúzió funkcióját veszi fel. Mindhárom müben fiktív névviselőt jelölő intertextuális nevekkel találkozunk, melyek irodalmi háttérismeretek mozgósításában érdekeltek (VÁCZINÉ TAKÁCS 2018: 34). Az ily módon létesülő párbeszéd pedig pretextus és poszttextus kapcsolatának hol összeillö, megerősítő, hol széttartó, ironikus jellegére világít majd rá. Ezt megelőzően azonban indokolt egy rövid elméleti kitérőt tenni a megközelítési szempontok árnyalása érdekében.

2. Eredet és változás. Az azonos nevet viselő és egymásra valamilyen tekintetben hasonlító szereplök státuszát és kölcsönviszonyát UGO MARGOLIN az eredeti (original) és a változat (version) fogalompár segítségével határozta meg. Legegyszerübb a helyzet akkor, írja, ha tisztázott a müvek kronológiája, és a szövegek láncola- 
tában elkülöníthető az eredeti történet, ahol először bukkant fel a szereplö. Minden későbbi előfordulása ugyanis ehhez mérten, ehhez viszonyítva változattá minősül át. A gyakorlat viszont azt mutatja, hogy nem határozható meg mindig ennyire egyértelmủen az eredet(i), ez ugyanis gyakran több forrásból származó információkból áll össze. MARGOLIN ezért különbséget tesz abszolút eredeti és másodfokú, azaz szintetikus vagy eklektikus eredeti szereplö között (MARGOLIN 2017: 158).

Olvasóként az eredeti és a feltételezett változat konfrontációjakor a közösen birtokolt tulajdonságok számát és jellegét tesszük mérlegre, illetve azt, hogy ezek mennyire kompatibilisek egymással. Tegyük hozzá, hogy a hiányok természetesen legalább annyira fontosak, beszédesek lehetnek ilyenkor, mint az egyezések, nem beszélve továbbá azokról a hozzáadott vonásokról, amelyekkel az áthelyezésen, kiegészítésen vagy mutáción alapuló újraírás (DOLEŽEL 2003: 197-221) szerzője egészítheti ki az eredeti figura portréját. Az idézett narratológus szerint a tulajdonságok három köre érdemel kiemelt figyelmet ebből a szempontból: 1. a cselekvő partnerek identitása, tér- és időbeli lokalizációja; 2. a szereplő által betöltött narratív szerepkörök és ebből eredő funkciók; 3. külső, fizikai tulajdonságok és a belső, pszichológiai jellemzők (jellem, alkat, hajlam) (MARGOLIN 2017: 162). A felosztást Poirot példáján szemléltetve: 1 . Hercule Poirot világhírü, belga származású magándetektív, aki az 1920-as évektől kezdve Angliában él, s gyakran barátja és krónikása, Arthur Hastings kapitány társaságában old meg bünügyi eseteket. 2. Poirot kivételes intelligenciájú detektív, aki a logikai következtetés segítségével oldja meg a rejtélyt, és leplezi le a tettest. 3. Poirot alacsony termetü, különös ismertető jegye a tojás alakú fej, a nagy, gondosan ápolt bajusz, zöld szem. Rendszerető, hiú, takarékos, édesszájú.

A két azonos nevü szereplő közötti hasonlóságnak különböző fokozatai lehetnek, melyek - némi egyszerúsítéssel élve - a teljes átfedéstől a tulajdonságok részleges közös metszetén át a pusztán névleges azonosságig terjednek. A név önmagában tehát még nem szavatolja az eredeti és a változatnak tekintett szereplö identikusságát, hiszen elképzelhető, hogy hamis elvárás felkeltésében érdekelt írói stratégia részeként a néven kívül semmilyen más közös jegy nem társul az új szereplőhöz. Másként fogalmazva: kiderülhet, hogy az illető nem a leszármazottja, csupán a névrokona az eredetinek. Mint ahogy lehetséges olyan eset is, hogy a név ugyan (az eredetiétől többé vagy kevésbé) eltérő, de a külső és a belső tulajdonságok, illetve a narratív funkciók tekintetében nagyfokú az egyezés a két alak között.

Az általam választott három elbeszélő mü is tükrözni kívánja ezeket a fokozatbeli eltéréseket. Baráth Katalin A belga című novellája a tökéletes megfelelés példája név és karakter tekintetében egyaránt. De fogalmazhatunk úgy is, hogy a magyar szerző nem teremtett új szereplőt és új nevet, csupán „kölcsönvette” egy másik, korábban már létező fikciós világ lakóját. José Carlos Somoza regényének, az Athéni gyilkosok címü münek a cselekménye ugyan jelentős térbeli, időbeli és kulturális eltéréseket mutat, mégis számos jól felismerhető vonáson keresztül füzi szorosra a föszereplö kapcsolatát Agatha Christie detektív hősével. Josef Škvorecký novellájában, a Nők a volán mögött című alkotásban pedig mind a név, mind a tulajdonságok három csoportja vonatkozásában csupán részleges vagy látszólagos egyezés mutatható ki. Nem bizonyítható, hogy e három Poirot-változat 
az első, A titokzatos styles-i eset című regényt tekintette volna irányadó mintának. Valószínübbnek látszik, hogy esetükben a Poirot-történetekből absztrahált másodfokú, szintetikus eredetivel van dolgunk.

3. Baráth Katalin: A belga. Baráth Katalin 2010-ben megjelent novellája egy térbeli áthelyezésen alapuló crossover történet (BENYOVSZKY 2016), melyben történelmi krimisorozatának visszatérő amatőr nyomozó hőse, Dávid Veronika Hercule Poirot-val találkozik Budapesten egy nyilvános bünügyi demonstráción. A már akkor hírnevet szerzett detektív azért érkezik a magyar fóvárosba, hogy egy ékszerrablási ügy megoldásán keresztül szemléltesse módszerének hatékonyságát. A Nő című lap újságírójaként erről az eseményről kell Veronnak tudósítania. Hiába azonban a munkába állított szürke agysejtek kivételes teljesítménye, a szinte tévedhetetlen logika, a magyar arisztokratikus körök politikai érdekei miatt nem sikerül letartóztattatnia a valódi tettest. Az ügyet eltussolják, egy ártatlan szabót vetnek börtönbe a gróf helyett; az igazságra nem derül fény.

A címből még csak sejthető, az elbeszélő által folyamatosan adagolt információknak köszönhetően azonban egyre bizonyosabbá válik, hogy a Pestre érkező illusztris vendég Agatha Christie nyomozóját takarja. Először azt tudjuk meg, hogy egy belga rendőrparancsnokról van szó, aki azért jön, hogy a „Logikus Útnak" nevezett módszerébe avassa be a magyar kollégákat. A nevét a lap szerkesztője kétszer is tévesen adja meg: Poitor úrnak (Baráth 2010: 287), illetve Hercule Poitor-nak (Baráth 2010: 288) nevezi. Főhősünk láthatóan nem tud egykönnyen napirendre térni sem a név, sem a származási ország felett: „És pontosan hol lelem ezt a nagytiszteletü, monsieur Poi... kicsodát? [...] Hercule? De hát ilyen név nem is létezik - hitetlenkedett. - Ahogy ez a Belgaország sem!" (Baráth 2010: 288) Kolléganője lapszusa miatt a személyes találkozás alkalmával aztán ő is Poitor kapitány-nak szólítja a detektívet, aki erre elég indulatosan reagál: „Poirot, mademoiselle. Po-i-rot, ahogy szerte a világon ismerik e dicsőséges nevet - szótagolta fojtott dühvel" (Baráth 2010: 291). Ekkor hangzik el először, viselőjének köszönhetően, helyesen a név a történetben. Dávid Veron azonban addigra magában csak „Bajuszember”-ként szólítja (Baráth 2010: 290) a nálánál is egy fejjel alacsonyabb termetü, ,kifogástalanul elegáns, lazacszínű öltönyben feszítő” idősebb férfit, akinek nyakán ,szinte teljesen kopasz és szinte tökéletesen tojásdad fej trónolt”, minek dísze ,egy gigantikus, fényesre suvickolt fekete bajusz” (Baráth 2010: 290) volt. Az idézett jellemzés olyan további, tipikusnak tekinthető tulajdonságokkal egészül ki a későbbiekben, mint a kényelmetlen lakkcipő viselése, a macskaszerü pillantás (Baráth 2010: 301), a szürke agysejtekre való hivatkozás (Baráth 2010: 292), illetve a francia szófordulatok gyakori használata.

Baráth Katalin tehát következetesen tartja magát a Christie-müvekből kirajzolódó Poirot-portréhoz, s annak szellemében alkotja meg a maga hősét. E nagyfokú, mondhatni maradéktalan hasonlóságnak és a névazonosságnak köszönhetóen éppen ezért olvasóként hajlamosak vagyunk a valódi Poirot-t látni a figurában. Ezt erősíti továbbá az időbeli egyezés is: az események ,a huszadik század első évtizedében" (Baráth 2010: 296) játszódnak, s az Agatha Christie müveiből összeállított Poirot-életrajzból tudható, hogy a belga detektív 1904-ben lépett ki a rendőrségtől, 
s magánnyomozóként dolgozott tovább (BENSON 2004: 345). A magyar szerző novellájában még rendőrtisztként emlegetik. A névtorzítás, a nyelvi idegenség legyőzésének nehézségein túl, az országban uralkodó viszonyok „torzságára” is utalhat. Poirot egy olyan országban találja magát, ahol nem elég, hogy még a nevét sem képesek megjegyezni és helyesen kiejteni, de ahol az igazságszolgáltatás zavartalan és pártatlan müködése, a nemesi elöjogok és a politikai nyomásgyakorlás miatt, korántsem biztosított. Nyomozói kudarca nem képességeire, hanem a Monarchiában uralkodó állapotokra vet rossz fényt.

Végezetül hadd térjek ki egy névattitüddel kapcsolatos észrevételre. Hercule Poirot-t a családneve és az akcentusa miatt számos esetben nézik franciának (e hamis vélekedést ő általában illedelmesen, ritkább esetben némi nyomatékkal igyekszik korrigálni), s nézik le ezért. Christie ezzel a korabeli brit társadalom egyes tagjainak idegenekkel szemben táplált elöítéleteit figurázza ki. Az alacsony, nagybajuszú, piperkőc „francia” nyomozói tehetségének köszönhetően mindenkor rácáfol ezekre a rosszindulatú etnikai sztereotípiákra. A sikeresen megoldott bünügyek számának növekedésével a kezdetben lenéző, vagy jobb esetben elnéző magatartást csakhamar az elismerés és a csodálat váltja fel. A belga címü novella történetvilágában is találkozunk az eredeti történetekhez hasonló negatív reakciókkal ${ }^{1}$, azzal az el nem hanyagolható különbséggel, hogy a fennhéjázó és enyhén xenofób társadalmi miliőn vett elégtétel ezúttal elmarad: Poirot leforrázva távozik Budapestről, a magyar lapok gúnyos hangú cikkekben számolnak be a demonstráció eredményéről („,Felsült a francia”, „Hazánk rendőrei lefőzték a Nyugatot”, „Au revoir, Poirot”; Baráth 2010: 303), és zsenialitása csupán amatőr kollégája, Dávid Veronika előtt lesz nyilvánvalóvá.

4. José Carlos Somoza: Athéni gyilkosok. „A tömegben állt egy a la c s o n y, igen kö vér férfi, aki meg sem moccant, míg a többiek el nem szállingóztak. Hunyorítva, békés tekintettel szemlélte a holttestet, széles, á p o lt a rcán nyoma sem volt $s$ e m miféle ér z e le $m \mathrm{n}$ e k. Úgy tetszett, állva alszik: a távozók kikerülték, s rá sem pillantottak, akárha oszlop vagy kődarab lett volna." (Somoza 2003: 10; kiemelés: B. K.) Ezekkel a mondatokkal lépteti színre José Carlos Somoza történelmi krimijének, az Athéni gyilkosoknak (La caverna de las ideas, 2000) a főhősét. Később azt olvassuk, hogy az illető „vaskos ujjai szépen nyírt, ezüstös szakállának szélét simogatták", s amikor a tömeget oszlató katona gyengéd erőszakkal megpróbálja eltávolítani a holttest közeléből, azt a választ kapja tőle magyarázatul a késlekedésére: „Gondolkodtam”. Ezekből az információkból még nem igazán sejthető, hogy akiről szó van, az kapcsolatba hozható Hercule Poirot-val. Az általam kiemelt szavak azután nyerik el a jelentőségüket, $\mathrm{s}$ vállnak intertextuális allúzióvá, hogy elhangzik a férfi neve. Az áldozat anyjánál tett részvétlátogatása alkalmával ezzel az üzenettel küldi be úrnőjéhez az ajtónálló rabszolgát: „Menj, és mondd meg neki, hogy Héraklész Pontór jött el hozzá látogatóba." (Somoza 2003: 13; kiemelés: B. K.). A keresztnév azonossága (a Hercules görög névpárja)

${ }^{1}$ „Én ennek a nyavalyás békaevőnek a rágalmazásait nem vagyok hajlandó tovább hallgatni!“ kiált fel és vonul ki tüntetően a teremből egy idős férfi, mintegy válaszul Poirot rendőrséget gúnyoló megjegyzésére (Baráth 2010: 292). 
és a családnév hasonlósága szinte automatikusan asszociálja bennünk a belga detektív alakját, amibe könnyen beilleszthetök az alacsony, kövér termetre, az ápolt arcszőrzetre, a szenvtelen szemlélődésre és az elmélyült gondolkodásra vonatkozó kijelentések. Az olvasásnak ebben a pillanatában azonban még kérdéses, hogy a szereplő külsejéről, jelleméről és munkájáról később közölt adatok vajon megerösítik-e ezt a hipotézist (a kiadó nem bízott semmit a véletlenre, a hátsó borítón ugyanis a tartalomismertetés előtt ez áll: Az ,athéni Hercules Poirot” i. e. 300-ban).

Kijelenthető, hogy alapvetően igen, megerösítik előzetes elképzeléseinket. Kiderül róla, hogy egyedül él, igaz, nem agglegény, mint Poirot, hanem özvegyember (Somoza 2003: 15). Kötelességtudóként jellemzik őt (Somoza 2003: 16), s maga vallja meg a szimmetria és az arányosság iránti vonzódását: „Szeretem, ha egyszerü dolgok vesznek körül: egy asztal négyszöge, a poharak körei... elemi geometria. Munkám épp az ellenkező véglet: kibogozni a bonyolult szövevényeket" (Somoza 2003: 25). Mohó fügehabzsolása Poirot édességek iránti vonzódását juttathatja eszünkbe. Szinte teljesen kopasz feje van, csupán néhány őszülő hajszál virít rajta (,vaskos, csonka kúp, tetején rövid, ezüstös mohahajzat”; Somoza 2003: 26). S ami a leglényegesebb: az emberek körében csak a Rejtélyek Kibogozója-ként emlegetik. Nemegyszer a narrátor is Rejtélybogozó-nak nevezi öt. Egy rabszolgafiú munkáját érintő kérdésére felelve azt mondja: ő olyan valaki, akinek a feladata „véleményt mondani titokzatos dolgokról” (Somoza 2003: 99). Megbízója pedig azzal indokolja választását, hogy „ha a jövőt akarjuk megismerni, a delphoi szentélyhez kell fordulnunk, ha azonban azt akarjuk megtudni, mi történt a múltban, elegendő, hogy felfogadjuk a Rejtélyek Kibogozóját" (Somoza 2003: 34). Pontór sikeres a munkájában, s Poirot-hoz hasonlóan a szerénység nem tartozik az erényei közé: „ne feledd, hogy egész Hellász legjobb Rejtélybogozóját szerződtetted" - jelenti ki egy alkalommal ő maga (Somoza 2003: 60). Az athéni közösség általi megítélése viszont - számos későbbi, modern kori kollégájához hasonlóan - ambivalens: „foglalkozása hírnevet szerzett neki, e mesterséget azonban legtöbbjük közönségesnek tartotta" (Somoza 2003: 171-172).

Az i. e. 300-ban játszódó bünügyi cselekmény középpontjában a Platón Akadémiáját látogató ifjak rejtélyes halála áll, ennek kinyomozására kérik fel Pontórt² Látható, hogy Somoza, amennyire azt a korabeli reáliák engedik, milyen ügyesen mozgósítja és aktualizálja a Christie müvek Poirot-ra vonatkozó adatainak széles körét. Megalkot egy olyan, az eredetire több tekintetben is emlékeztető, de vele nem azonos szereplöt, egy hasonmást, aki egy jóval korábbi kor és egy eltérő ország lakója. Fogalmazhatunk úgy is, hogy visszavezeti a figurát a keresztnév kulturális gyökereihez. A névasszociációval párosuló térbeli és időbeli áthelyezés fura kettősséget eredményez: a fikciós történet ideje szempontjából Héraklész Pontór a belga detektív előképének tekintendő, a regény megjelenési ideje felől nézve viszont természetesen annak irodalmi leszármazottja, változata.

${ }^{2}$ A pontosság kedvéért hozzá kell tenni, hogy a rafinált metafikciós poétikát követő regény cselekménye két síkon zajlik. A második, az Athéni gyilkosok című anonim regény fordítójának megjegyzéseit és életsorsát figyelemmel kísérő szál lábjegyzetekben bontakozik ki. Ez utóbbinak az elemzésétől terjedelmi okokból, s mert nem kapcsolódik közvetlenül a névtani problematikához, ezúttal eltekintek. 
Míg a magyar példában a családnév, addig itt a keresztnév idegenszerú konnotációja, pontosabban annak hiánya érdemel figyelmet. Az Hercule Poirot név kettős idegenséget konnotál. A keresztnév az antikvitás, a családnév pedig, láthattuk, a franciaság jelentésmozzanatát nyomatékosítja, ami a Christie-történetek társadalmi és kulturális közegében a különösség, a kivételesség, egyúttal azonban a komikusság benyomásának felerősödését is maga után vonja. Az Hercule ritka névnek számít, olyannyira, hogy egyesek a „valódiságában” is kételkednek (1. Dávid Veronika idézett reakcióját). Viselöjének testi adottságai a mitológiai háttérismeretek kontextusában fokozottabban váltanak ki Christie egyes szereplőiből gúnyos megnyilvánulásokat (nem elég, hogy apró termetü, tojásfejü, tetejében még Hercule-nek hívják). Somoza regényében viszont, tekintettel a cselekmény tér- és időbeli lokalizációjára, eltünik a keresztnév különösségének és idegenszerüségének érzete, érdekes módon viszont nem válik ironikus reflexió tárgyává sem Pontór alacsonysága, sem korpulens alkata. Annak ellenére sem, hogy a Héraklész tizenkét feladatára tett nyílt és rejtettebb utalások ugyanúgy végigkísérik az egyes fejezeteket, miként a Herkules munkáiban. A figura különössége és kivételessége a foglalkozásából eredő társadalmi kívülállásban őrződik meg.

5. Josef Škvorecký: Nők a volán mögött. Ronald A. Knox angol teológus, bibliafordító és krimiszerző 1929-ben, egy detektívtörténet-antológiához írott előszóban afféle múfaji tízparancsolatot tett közzé, melyben a mystery story racionális szellemiségének és az olvasóval szembeni sportszerüségének megőrzését szolgáló elvárásokat és szabályokat fogalmazott meg (magyarul 1. KESZTHELYI szerk. 1985: 220-224). Ezt az egy évre rá megalakuló, a kor jeles brit krimiíróit tömörítő Detektív Klub irányadónak fogadta el a tagjai számára.

Erre reagálva a müfaj teoretikusaként is ismert cseh író, Josef Škvorecký 1973-ban Vétkek Knox atya számára (Hř́́chy pro pátera Knoxe, 1973) címmel egy olyan novelláskötetet jelentetett meg, melyben minden történet szándékosan megy szembe e híres szabálygyüjtemény valamelyik pontjával. (A müvet a saját fordításomban idézem.) Ezekben a hivatalos rendőröket lepipáló amatőr nyomozó szerepkörét (az első novella kivételével) rendhagyó módon egy bárénekesnő, a gender szempontból sokatmondó nevet viselő Eva Adamová tölti be, s egyben ő a narrátor is. A kiválasztott történet, a Nők a volán mögött (Ženy za volantem) Olaszországban, közelebbről Rimini környékén játszódik, ahol hősünk egy fiatal stoppos lány gyilkosának kézre kerítésében segédkezik. Miként más alkalommal, ezúttal is véletlenül keveredik bele az ügybe. Tanúként hallgatják meg, de ő csakhamar felcsap detektívnek.

Szükség is van rá, a nyomozást vezető kapitány ugyanis nincs a helyzet magaslatán. Öt gyanúsított közül kell kiválasztania az elkövetőt, miközben híján van bármifajta bizonyítékértékủ nyomnak. Ötlete nincs arra, hogy jusson közelebb a megoldáshoz, ezért tanácstalan és kétségbeesett. Kedélye is hullámzó: az egyik pillanatban még lelkes, a következőben pedig már a teljes lemondás lesz úrrá rajta. Sủrün váltogatja a diadalittas fenyegetőzést és a siránkozást. Ráadásul hagyja magát befolyásolni egy szemrevaló női tanú által, aminek eredményeként aztán egy ártatlan férfit tartóztat le. 
A kapitányt Hercule Potarot-nak hívják.

Eva azt gyanítja, hogy a névadás mögött ,talán a bizonyos értelemben olvasott szülők tréfája” (Škvorecký 1991: 67) húzódik meg. Az olvasottság Agatha Christie vonatkozó történeteinek az ismeretét jelenti, így az előző példával ellentétben Poirot itt már egyértelmüen költött, azaz a szereplök valóságosnak tekintett világához képest fiktív irodalmi szereplöként válik a gúnyos értelmü célzás tárgyává. Mintha a rendőrt a neve predesztinálta volna arra, hogy ezt a szakmát válassza. Viszont már az eddig elmondottakból nyilvánvaló, hogy az Athéni gyilkosokkal ellentétben a részleges névegyezés ezúttal nem teljesíti az elvárásainkat. A harsányan, szenvedélyesen, széles gesztusok kíséretében beszélő olasz rendőrt egyedül a neve és a foglalkozása köti össze Poirot-val, de ez utóbbi gyakorlásával kapcsolatban már súlyos kifogások merülnek fel. Potarot munkáját nem a „szürke agysejtek” irányítják, s nem jellemzi sem a higgadt szemlélődés, sem az apró részletek megfigyelése, de a logikai következtetések módszerének sikeres alkalmazása sem tartozik az erősségei közé. Azzal, hogy majdnem futni hagyja a gyilkost, nem szolgál rá a híres előd nevére, inkább szégyent hoz rá. Okkal olvasható tehát a novella elején található szereplőlistában a neve mellett a következő meghatározás: „nem hozott valami nagy dicsőséget majdhogynem névrokonának” (Škvorecký 1991: 64).

Eva, látván a kapitány vakságát és agresszív tétovaságát, tréfából Potrat-nak szólítja öt, ami csehül 'elvetélés'-t jelent (magában tovább játszik a név kicsinyítő képzős alakjával, s hol Potráteček-ként, hol Potrátek-ként hivatkozik rá). A névtévesztés szándékosságáról mit sem sejtő kapitány ugyanolyan fojtott indulattal javítja ki az énekesnőt, mint tette ezt Baráth Katalin novellájában Poirot. A szójáték utalhat egyfelől a nyomozás során elkövetett melléfogására és me d d ő igyekezetére a tettes kézre kerítésében, másfelől értelmezhető akként is, hogy Potarot egy e $1 \mathrm{v}$ e $t$ é $1 \mathrm{t}$ Poirot. Az írói névadás az intertextuális iróniát erősíti fel: az olasz kapitány a belga detektív paródiája. Jó példája ez annak, hogy miként válik a belső tulajdonságra utaló beszélő név a paródia hathatós nyelvi eszközévé (SLÍz 2006: 293).

6. Összegzés. Baráth Katalin Hercule Poitorja/Poirot-ja és Juan Carlos Somoza Héraklész Pontórja megérdemelten viseli a nagy elödével teljesen, illetve részben egyező nevét, Škvorecký Hercule Potarotja viszont csak alaptalanul „bitorolja” azt. Bármennyire különbözzenek is azonban egymástól, közös ősre vezethetők vissza. Ezek a hol szorosabb, hol lazább rokoni szálak pedig nagyrészt az összecsengő, egymásra rímelő neveknek köszönhetően válnak szembetünővé, melyek komparatív olvasásra felhívó jelként funkcionálnak. Hercule Poirot neve és alakja pedig afféle elhallgatott, de odaértett - peirce-i értelemben vett interpretánsként alakítja olvasói konkretizációnkat: rá való tekintettel, felőle nézve ítéljük meg az utódok külsejét, jellemét és tetteit. Ennek következtében egymásra hasonlító elemeket tartalmazó interikonikus jelsor jön így létre, melynek azonos jeltárgya van (SzÍvós 2013: 207). Ez a lánc, az intertextuális írói nevek természetéből következően, nemcsak a jövő, hanem a múlt irányában is nyitott, azaz viszszamenőlegesen is meghosszabbítható. Hiszen Poirot sem elödök nélkül született. Ahogy azt a szakirodalom már részletesen feltárta, Agatha Christie a figura meg- 
alkotásakor közvetlenül vagy közvetetten inspirálódott mindenekelött Arthur Conan Doyle (Sherlock Holmes), Gaston Leroux (Joseph Rouletabille), Robert Barr (Eugen Valmont), Alfred Edward Woodley Mason (Inspector Hanaud) és Marie Belloc Lowdnes múveiből (MAIDA-SPORNICK 1982: 86-90)³. Témánk szempontjából az utolsóként említett írónő visszatérő figurája érdemel kiemelt figyelmet. A francia rendőrség felettébb hiú, nyugalmazott nyomozóját ugyanis Hercules Popeau-nak hívják, akinek egyik kalandja 1943-ban, tehát négy évvel Agatha Christie kötete előtt A labour of Hercules címmel jelent meg novella formájában. Az idézett szerzőpáros hangsúlyozza, hogy Lowdnes írta helyesen, a francia írásmódnak megfelelően a keresztnevet, s Agatha Christie volt az, aki valamilyen okból elhagyta a szózáró $s$ betüt. Nyitva hagyják a kérdést, hogy ez vajon csupán egyszerü elírás volt-e a részéről, vagy komikus szándékot sejtető csonkítás történt-e (MAIDA-SPORNICK 1982: 88). Jóllehet az írónő pusztán esztétikai okokkal magyarázta a névmódosítást ${ }^{4}$, a felsorolt hatástörténeti összefüggések fényében nem kizárt az sem, hogy a szövegközi alakpárhuzamokat létesítő névtorzítás terén, minden későbbi újraírás szerzőjét megelőzve, ő maga járt elöl példával.

Kulcsszók: névtorzítás, alakpárhuzam, Hercule Poirot, krimi.

\section{Felhasznált források}

Baráth Katalin 2010: A belga. In: Baráth Katalin, A fekete zongora. Agave Kiadó, Budapest. 285-303.

Christie, Agatha 1990a. A titokzatos styles-i eset - Függöny. Ford. Dezsényi Katalin - Gy. Horváth László. Európa Könyvkiadó, Budapest.

Christie, Agatha 1990b. Herkules munkái. Ford. Csák István. Hunga Print, Budapest.

Škvorecký, Josef 1991. Hřichy pro pátera Knoxe. Mladá fronta, Praha.

Somoza, José Carlos 2003. Athéni gyilkosok. Ford. Dobos Éva. Atheneum, Budapest.

\section{Hivatkozott irodalom}

BENYOVSZKY KRISZTIÁN 2016. Keresztül-kasul a szövegeken. Helikon 62: 388-398.

Bunson, Matthew 2004. Agatha Christie világa. Ford. Cserna György - Tasi Júlia. Magyar Könyvklub, Budapest.

DoleŽEL, LuBOMír 2003: Heterocosmica. Karolinum, Praha.

ECO, UMBERTO 2009. On the ontology of fictional characters: A semiotic approach. Sign System Studies 37: 82-97.

${ }^{3}$ Feltétlenül említést érdemel még Frank Howell Ewans teremtménye, Jules Poiret, a francia titkosrendőrség Londonban élő nyugalmazott felügyelője, akinek kalandjai 1909-1910 között jelentek meg folyóiratban. A kritikusok egy része feltételezi, hogy az akkor 19 éves Agatha Christie olvashatta őket. (Ezekről a kérdésekröl 1. OsoBA 2000.)

${ }^{4}$ „Valami grandiózus név kellett. Olyan név, amilyet Sherlock Holmes és a családja választott volna... Hercules: ez jó név lesz. A vezetékneve már keményebb diónak bizonyult. Nem is tudom, hogy végül miért maradtam a Poirot névnél... Csakhogy nem illett a Herculeshez, inkább az Hercule-höz. - Hercule Poirot. Így már rendben volt.” (Idézi BUNSON 2004: 353.) 
KeSZTHELYI TIBOR szerk. 1985. A krimi. Gondolat, Budapest.

MAidA, PATRIzIA D. - SPORNICK, Nicholas B. 1982. Murder She Wrote: A Study of Agatha Christie's Detective Fiction. Bowling Green State University Popular Press, Bowling Green.

Margolin, Ugo 2017. Postavy a jejich verze. In: MiHAilescu, CALIN-ANDREI - HAMARNEH, WALID szerk., O fikci nově. Academia, Praha. 153-181.

OsOBA, MARGARET 2000. The strange case of Monsieur Poiret: was he the inspiration for Agatha Christie's Hercule Poirot? Book and Magazine Collector 195: 27-34.

SLÍZ MARIANN 2006. A beszélő nevek mint a posztmodern eszközei. Magyar Nyelvőr 130: 290-301.

SzÍvÓs MiHÁLY 2013. A jeltől a kódig. Rendszeres szemiotika. Loisir Kiadó, Budapest.

VÁCZINÉ TAKÁCS EDIT 2018. Az irói névadás sajátosságai Karinthy Frigyes müvei alapján. Magyar Névtani Értekezések 6. Magyar Nyelvtudományi Társaság - ELTE BTK Magyar Nyelvtörténeti, Szociolingvisztikai, Dialektológiai Tanszéke, Budapest. https://doi.org/10.26546/4890065

\section{Distortion of names and parallelism of characters in crime fiction}

The paper uses the examples of three narrative pieces, two crime stories and a novel, to demonstrate the role of the distortion of names in forming characters and orienting interpretation. The point of departure is Agatha Christie's popular character, Hercule Poirot, and the comparative investigation targets pieces involving characters that resemble him in one way or another. In these pieces, full or partial identity of names opens the way to intertextual interpretation: the character's name takes up the function of intertextual allusion. Katalin Baráth's short story The Belgian is an example of full identity both in name and in character. The protagonist of José Carlos Somoza's novel, the plot of which takes place in ancient times, corresponds to Poirot in a number of respects, despite the significant spatial, temporal, and cultural differences. Finally, in Josef Škvorecký's short story Women behind the Steering Wheel, it is only partial or apparent correspondence that can be found between the two characters.

Keywords: distortion of names, parallelism of characters, Hercule Poirot, crime fiction. 